activated ATPase. A possible target of aldosterone. J. clin. Invest. 55, 655-660 (1975)

8) Wlsilenfleder, C., Arevalo, G.J., Baranowski, R.L., Kurtzman, N.A. and Katz, A.I.: Relationship between mineralocoticoids and renal $\mathrm{Na}$, K-ATPase; sodium reabsorption. Am. J. Physiol. 233, F593 599 (1977)

\title{
DIFFERENCES IN SPEED AND DEGREE OF MYOSIN B SUPERPRECIPITATION IN THE PRESENCE OF DIVALENT CATIONS
}

\author{
Michio YAJIMA and Kazumi TAKEYA \\ Department of Pharmacology, Aichi Medical University, \\ Nagakute, Aichi 480-11, Japan
}

Accepted October 2, 1978

Efrorts have been made to acquire precise quantitative evaluation for the superprecipitation of contractile protein myosin B. Ebashi first reported a method for evaluating the degree of superprecipitation by turbidimetry at $660 \mathrm{~m} / \mu$ (1). Watanabe used two parameters for study of superprecipitation; the time required to reach the half maximum increase in turbidity $\left(t_{0.5}\right)$ and the maximum increase in turbidity* ( $4 O D$, extent) (2). In the present experiments, we introduced the velocity of superprecipitation at $t_{0.5}\left(\mathrm{Vt}_{0.5}\right)$ in addition to the above two parameters (Fig. 1). The objective was to obtain information concerning the effects of $\mathrm{Ca}, \mathrm{Mg}$ and $\mathrm{Mn}$ on these three parameters.

Myosin B was extracted from the leg muscle of rabbit (1). The superprecipitation of myosin B was continuously measured using a spectrophotometer at $660 \mathrm{~m} \mu$ (Hitachi 100-01) and the findings were displayed on paper (National pen recorder VP-654B). The reaction mixture in a total volume of $3.0 \mathrm{ml}$, contained $0.6 \mathrm{mg} / \mathrm{ml}$ myosin $\mathrm{B}, 0.06 \mathrm{M}$ Tris-maleate

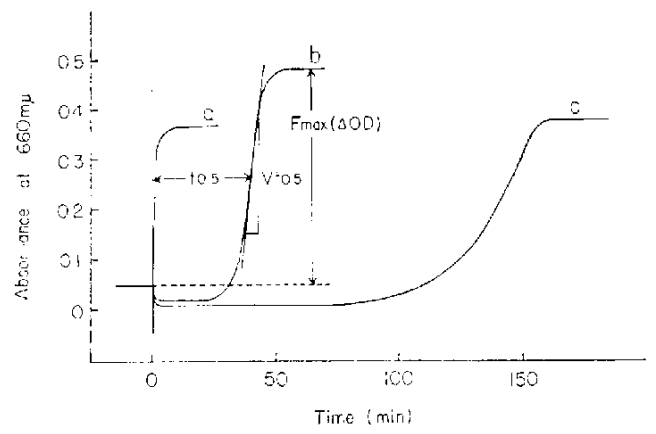

FIG. 1. Parameters in time course of the superprecipitation of myosin B. Parameters

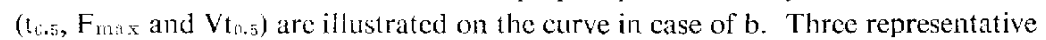
cases in the time course of superprecipitation are shown: a, control (no added divalent cations); $b$, presence of $10^{-4} \mathrm{M} \mathrm{MnCl}_{2} ; c$, presence of $10^{-4} \mathrm{M} \mathrm{MgCl}_{2}$.

$*$ We termed this parameter $F_{1 m: 1 \times}$. 
buffer ( $\mathrm{pH}$ 6.8) and varying amounts of divalent cations $\left(\mathrm{CaCl}_{2}, \mathrm{MgCl}_{2}\right.$ and $\left.\mathrm{MnCl}_{2}\right)$. The reaction was started by addition of $0.5 \mathrm{ml}$ of $6 \mathrm{mM}$ ATP- $\mathrm{Na}_{2}$ (final conc. $1 \mathrm{mM}$ ). To avoid fluctuation of the results, special attention was paid to the adjustment of ionic strength with $\mathrm{KCl}$ solution $(0.9 \mathrm{M})$ at 0.17 and to maintain the temperature of the mixture at $26 \pm 0.5^{\circ} \mathrm{C}$. The endogenous $\mathrm{Ca}$ and $\mathrm{Mg}$ contents of the reaction mixture were estimated by atomic absorption spectroscopy at about 8 and $13 / 2 \mathrm{M}$, respectively. The concentrations of ionic form of these metals were presumably at a concentration below $1 / 1 \mathrm{M}$, considering that the effects on $\mathrm{t}_{0.5}$ were significant at $\mathrm{p}<0.05$ (Fig. 2a).

A time point of the onset of superprecipitation was delayed by both $\mathrm{Mg}$ and $\mathrm{Mn}$ (Fig. 1). Time required to reach half maximum increase in turbidity of myosin B with $\mathrm{Mg}$ was markedly longer than that with $\mathrm{Mn}$; i.e., the values of $\mathrm{t}_{0.5}$ in the presence of $10^{-4} \mathrm{M}$ of either $\mathrm{MgCl}_{2}$ or $\mathrm{MnCl}_{2}$ were $135 \div 6.9 \mathrm{~min}$ and $39 \pm 0.9 \mathrm{~min}$, respectively. Calcium produced a dose-dependent shortening of $\mathrm{t}_{0.5}$ and this effect was more pronounced in the presence of $\mathrm{Mg}$ than that of Mn (Fig. 2a). The level of maximum increase in turbidity of superprecipitation $\left(\mathrm{F}_{\max }\right)$ was observed to be elevated by the presence of $\mathrm{Mn}$ about $30 \%$ over the control value. Electromicroscopic examinations, however, showed no special findings in the ultrastructure of the superprecipitated myosin B (unpublished data). Calcium in a low concentration $\left(10^{-6}-10^{-4} \mathrm{M}\right)$ did not affect the superprecipitation, while, a higher concentration $\left(10^{-3}-\right.$ $10^{-2} \mathrm{M}$ ) produced an increase in $\mathrm{F}_{\max }$ in the presence of $\mathrm{Mg}$ or $\mathrm{Mn}$ (Fig. 2b). The velocity of superprecipitation at $t_{0,5}$ in the control experiment was as fast as $0.70(1 \mathrm{OD} / \mathrm{min})$, whereas in the presence of $\mathrm{Mg}$ or $\mathrm{Mn}\left(10^{-4} \mathrm{M}\right)$ the velocity slowed down 100.008 or 100.042 . Between $\mathrm{Ca}$ and other divalent cations an antagonistic relation was found in $\mathrm{Vt}_{0.5}$ (Fig. 2c); the velocity decreased by $\mathrm{Mg}\left(10^{-4} \mathrm{M}\right)$ was restored by adding $\mathrm{Ca}$ in a dose-dependent manner,
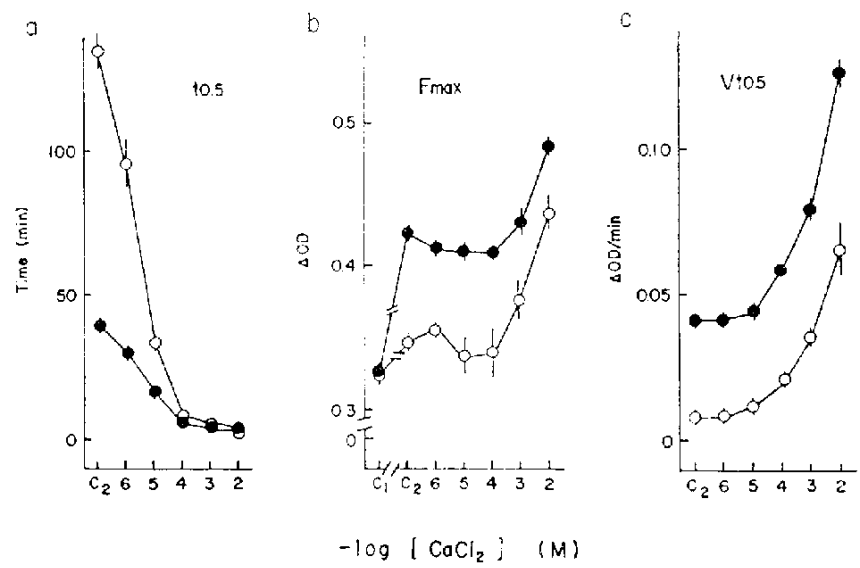

Fro. 2. Efrects of $\mathrm{Mg}$ and $\mathrm{Mn}$ on the paramelers of superprecipitation under varied $\mathrm{CaCl}_{2}$ concentrations. Degree of superprecipitation was evaluated by change in turbidity of myosin $B$. a, $t_{\$ .5}$ : time required to reach the half maximum increase in turbidity; $b, F_{n 11 x}$ : the maximum increase in turbidity; $c, V_{0.5}$ : velocity of super-

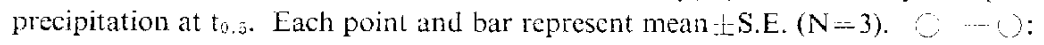
$10^{-1} \mathrm{M} \mathrm{MgCl}_{2}$. $-10^{-4} \mathrm{M} \mathrm{MnCl}_{2} . \mathrm{C}_{1}$ : no added divalent cations sich as $\mathrm{Mn}, \mathrm{Mg}$ and $\mathrm{Ca} . \mathrm{C}_{2}$ : no added $\mathrm{CaCl}_{2}$. 
e.g., $\mathrm{CaCl}_{2}$ of $10^{-4}, 10^{-3}$ and $10^{-2} \mathrm{M}$ increased the velocity by an average of $2.7,4.5$ and 8.3 times as compared with the control in the presence of $\mathrm{Mg}$. The suppressive effect of $\mathrm{Mg}$ on $\mathrm{Vt}_{0.5}$ developed concentration-dependently in the range tested from $10^{-6} \mathrm{M}$ to $10^{-4} \mathrm{M}$ (data not shown). These results indicate that the speed of superprecipitation is regulated by $\mathrm{Ca}$ and $\mathrm{Mg}$ in an antagonistic rclation.

In comparison with $\mathrm{Mg}$ and $\mathrm{Mn}$ at an equimolar basis of $10^{-4} \mathrm{M}, \mathrm{Mg}$ suppressed $\mathrm{Vt}_{0.5}$ with a potency 5 times grcater than $\mathrm{Mn}$. Calcium also accelerated the onset $\left(\mathrm{t}_{0.5}\right)$ and velocity $\left(\mathrm{Vt}_{0.5}\right)$ of the superprecipitation of myosin $\mathrm{B}$ in the presence of $\mathrm{Mn}$; c.g., $\mathrm{Vt}_{0.5}$ was accelerated twice by the addition of $10^{-3} \mathrm{M} \mathrm{CaCl}_{2}$, however, $\mathrm{Mn}$ inhibited $\mathrm{Vt}_{0.5}$ concentration-independently in the range from $10^{-6}-10^{-2} \mathrm{M}$ (data not shown). This prolongating effect on $\mathrm{t}_{0.5}$ is presumably in accord with the results in reports that clearing response on superprecipitation or inhibitory effect on ATPase activity of myosin B was strengthened by $\mathrm{Mn}$ as well as $\mathrm{Mg}$ $(3,4)$. The mechanism of increased $F_{\max }$ by $\mathrm{Mn}$ is obscure from the present experiments, however, the paradoxical positive inotropic effect of $\mathrm{Mn}$ on isolated guinea-pig myocardium has been reported (5). It has also been reported that $\mathrm{Mn}$ blocked $\mathrm{Ca}$ influx in various excitable cells $(6,7,8)$. Moreover, the evidence that $\mathrm{Mn}$ carried transmembrane inward current suggests that $\mathrm{Mn}$ directly affects the contractile protein complex $(9,10,11)$. The inhibitory effect of $\mathrm{Mn}$ on $\mathrm{t}_{0.5}$ or $\mathrm{Vt}_{0.5}$ would explain the negative inotropic effect of $\mathrm{Mn}_{n}$ in the early stage (12).

In summary, a new parameter $\mathrm{Vt}_{0.5}$, speed of superprecipitation is introduced in addition to $t_{0.5}$ and $F_{\max }$ (2). On these three parameters of superprecipitation, the influence of divalent cations, $\mathrm{Ca}, \mathrm{Mg}$ and $\mathrm{Mn}$ was analyzed.

\section{REFERENCES}

1) Ebashil, S.: Calcium binding activity of vesicular relaxing factor. J. Biochem. 50, 236-244 (1961)

2) Watanabe, S.: Relation between superprecipitation and ATPase of myosin B. J. Biochem. 68, 913-921 (1970)

3) Fuji, T. AND Maruyama, K.: Manganese-induced clearing response of actomyosin at low temperatures. Sci. Pap. Coll. gen. Educ., Univ. Tokyo 20, 163-169 (1970)

4) IshiKawa, Y. AND MARUYama, K.: Effect of metal ions on the ATPase activity of natural actomyosin. Zool. Mag. 73, 213-214 (1964)

5) Vifring, M.: Positive inotropic effect of manganese in the guinea-pig myocardium. Arch. Pharmacol. 297, R19 (1977)

6) Hagiwnra, S.: Membrane properties of the barnacle muscle fiber. Ann. N. Y. Acad. Sci. 137, $1015-1024$ (1966)

7) BaKer, P., MEves, H. ANd Ringway, E.B.: Effects of manganese and other agents on the calcium uptake that follows depolarization of squid axons. $J$. Physiol. 231, 511-526 (1973)

8) Konluardt, M., Bauer, B, Krause, H. and Fleckenstein, A.: Selective inhibition of the transmembrane $\mathrm{Ca}$ conductivity of mammalian myocardial fibers by $\mathrm{Ni}, \mathrm{Co}$ and $\mathrm{Mn}$ ions. Pfügers Arch. 338, 115-123 (1973)

9) OCHI, R.: Manganese-dependent propagated action potentials and their depression by clectrical stimulation in guinea-pig myocardium perfused by sodium-free media. J. Physiol. 263, 139-156 (1976)

10) Delahayes, J.F.: Depolarization-induced movement of $\mathrm{Mn}^{2+}$ across the cell membrane in the guinca pig myocardium. Circulation Res. 36, 713-718 (1975) 
11) Flkuda, J. AND Kawa, K.: Permeation of manganese, cadmium, zinc and beryllium through calcium channels of an insect muscle membrane. Science 196, 309-311 (1977)

12) TAKEYA, K. AND ReiTER, M.: Effect of divalent manganese ions on action potential and contractility of cardiac muscle. Arch. Phamacol. 275, 213-226 (1972)

\title{
EFFECTS OF d,1-PROPRANOLOL AND OTHER BETA ADRENERGIC RECEPTOR BLOCKING AGENTS ON MEMBRANE FLUIDITY OF ERYTHROCYTES
}

\author{
Shin-ichi AKIYAMA* and Hideki IGISU** \\ * Kyushir Cancer Center, 595 Notame, Minami-ku, Fukuoka 815, \\ and ${ }^{*}$ Institute of Health Science and Department of Neurology, Neurological \\ Institute, Facnlty of Medicine, Kyushu University, Fukwoha 812, Japan \\ Accepted October 18, 1978
}

In addition to the beta adrenergic receptor blocking action, propranolol has been known to be lipid soluble with local anesthetic properties (1). The local anesthetic activity of propranolol may account for the antiarrhythnic effects of the drug (2). It was reported that propranolol might change the structural state of membrane phospholipids of erythrocytes (3). We studied the effects of d,l-propranolol and other beta adrenergic receptor antagonists, practolol and pindolol, on the fluorescence polarization of DPH embedded in human erythrocyte membranes.

Erythrocyte membranes were prepared from human blood by hypotonic lysis (4). After discarding the serum and buffy coat carefully, red blood cells were washed 3 times with $0.85 \% \mathrm{NaCl}$ and hemolysed in $10 \mathrm{mM}$ Tris- $\mathrm{HCl}(\mathrm{pH} 7.4)$. The ghosts were suspended and centrifuged 5 tines in this buffer at $20000 \mathrm{~g}$ for $15 \mathrm{~min}$.. The membranes were stored at $-80^{\circ} \mathrm{C}$ until use. Fluorescence labeling of the erythrocyte membranes was done as described by Shinitzky and Inbar (5). 1,6-Diphenyl 1,3,5-hexatriene (DPH), which has been established as a fluidity probe for hydrocarbon regions of biological membranes and liposomes, was used (6). One volume of membrane suspension with the protein concentration of $0.4 \mathrm{mg} / \mathrm{ml}$ was mixed with the same volume of labeling solution; $2 \times 10^{-6} \mathrm{M} \mathrm{DPH}$ dispersion in $10 \mathrm{mM}$ Tris- $\mathrm{HCl}(\mathrm{pH}$ 7.4) which was freshly prepared by diluting a stock solution of $2 \times 10^{-3} \mathrm{M} \mathrm{DPH}$ in tetrahydrofuran. After thorough mixture and incubation for 1 hour at $25^{\circ} \mathrm{C}$, the labeled membranes were washed twice with $10 \mathrm{mM}$ Tris-HCl buffer ( $\mathrm{pH} 7.4$ ), resuspended in the same buffer to make the protein concentration $0.3 \mathrm{mg} / \mathrm{ml}$ and used in the experiments. Measurements of the intensity of the fluorescence were made using a Hitachi Spectrofluorometer, Modd MPF-4 (Hitachi, Ltd., Tokyo, Japan), equipped with polarizers and a thermostatic cell holder. Excitation was at $366 \mathrm{~nm}$ with a band pass of $10 \mathrm{~nm}$ and emission was measured at $427 \mathrm{~nm}$ (emission maximum) after passing through

* Present address: Department of Biochemistry, Oita Medical School, Oita 870, Japan 